\title{
ジオシンセティックスー土との原位置糜擦特性評価試験
}

\author{
宇都宮大学工学部助教授 \\ 今泉繁良 \\ 宇都宮大学工学研究科博士前期課程 野本哲也 \\ 宇都宮大学工学研究科博士後期課程 坪井正行 \\ 宇都宮大学工学部教授横山幸満
}

\begin{abstract}
概 要
近年、ジオメンブレンやジオテキスタイルは廃棄物処理場の遮水工材料として、広く用いられている。ジオシ ンセティックスと土との摩摖特性は、固定や法面の設計をするのに重要な要因である。この論文では、原位置で の摩擦特性を評価し得る簡易な試験装置を開発した。この試験装置を用いて、ローム地盤と排水用砂の上で、土 の含水比を通常状態と湿潤状態とに変えて試験を行った。用いたジオシンセティックスは、HDPE,EPDM,PVC など 6 種類のジオメンブレンと長繊維と短緎維の 2 種類のジオテキスタイルである。結果として、浸水状態の摩 擦係数は通常状態に比べて、ローム地盤で 70-80\%、砂地盤で 90\%となることがわかった。また、原位置で評価 された表面滑らかなジオメンブレンと短織維ジオテキスタイルとの摩摖係数は、実験室内で実施した直接せん断 試験の直応力せん断抵抗力関係とよい一致を示した。
\end{abstract}

\section{In-situ Frictional Tests for Geomembrane/Soil and Geomembrane/Geotextile Interface}

\author{
Shigeyoshi IMAIZUMI : Associate Professor of Utunomiya University, Japan \\ Tetsuya NOMOTO : Graduate Student of Utsunomiya University, Japan \\ Masayuki TSUBOI : Doctoral Student of Utsunomiya University, Japan \\ Yukimitsu YOKOYAMA : Professor of Utsunomiya University, Japan
}

\begin{abstract}
Geomembranes and geotextiles, recently, are becoming to be widely used as a component of liner system in waste landfill. The frictional characteristics on interface between geomembrane/soil and geomembrane/geotextile are very important factor to design liner's structure such as its anchorage or side slope angle. In this paper, convenient in-situ equipment to measure a frictional resistance between geomembrane/soil and geomembrane/geotextile was developed. The in-situ tests were conducted on two loam ground and on drain sand at construction site. The ground condition was prepared as natural moisture condition and submerged condition. The geosynthetics used included six geomembranes such as smooth HDPE, HDPE with spike, EPDM, TPO, PVC and reinforced CPE and two geotextiles such as continuous nonwoven and stapled nonwoven. As the results, it is found that the ratio of frictional coefficient estimated at submerged condition to one at natural condition is about $70-80 \%$ for loam ground while it is $90 \%$ for drain sand. The frictional coefficients between smooth surfaced geomembrane and stapled nonwoven geotextile estimated at in-situ tests is good agreement with the relationship between normal stress and shear stress obtained by direct shear tests in laboratory.
\end{abstract}




\section{ジオシンセティックス-土との原位置摩擦特性評価試験}

\begin{tabular}{lllll} 
宇都宮大学工学部 & 正会員 & & 今泉 & 繁良 \\
宇都宮大学工学研究科 & 学生会員 & 野本 & 哲也 \\
\multicolumn{1}{l|}{ 同 上 } & 正会員 & 坪井 & 正行 \\
宇都宮大学工学部 & & & 横山 & 幸満
\end{tabular}

\section{1.はじめに}

廃棄物処分場における遮水工の設計において、ジオシンセティックスと土との摩擦係数を知ることが必 要であることが多い。このために、摩擦係数の評価は室内での直接せん断試験の実施により数多く行なわ れてきた 1)2334)。しかし、実際の施工においてはジオシンセティックスが原位置の地盤上に敷設されること が一般的であることを考虑すると、含水比や密度が原位置のあるがままの状態でのジオシンセティックス と土との摩擦係数を評価することは特に重要である。

本研究においては、原位置摩摖特性を評価することができる試験装置を試作し、この試験装置を用いて 関東ローム、砂地盤と HDPE(高密度ポリエチレン)、EPDM(加硫ゴム)、PVC(塩化ビニール)、不織布など との摩擦特性を評価した。特に地盤が通常の状態と湿潤状態における摩摖係数の違いに着目して考察した。

\section{2.地盤およひジオシンセティックスの特性}

実験の対象とした原地盤は、宇都宮大学工学部構内のローム(以下、「構内ローム」)、栃木県芳賀郡芳 賀町八ッ木の宅地造成地内口ーム(以下、「八ッ木ローム」)、埼玉県羽生市処分場建設現場内の覆土用砂(以 下、「排水用砂」)の 3 箇所である。原地盤より採取した試料の物理的特性を表ー 1 に示す。

また、実験に用いたジオシンセティックスは、厚さ $1.5 \mathrm{~mm}$ の HDPE(高密度ポリエチレン)、EPDM(加 硫ゴム)、PVC(塩化ビニール)、TPO(熱溶着ゴム)、繊維補強 CPE および厚さ $3 \mathrm{~mm}$ のシボ付き HDPE(シボ 長 $5 \mathrm{~mm}$ )のジオメンブレンと長織維(厚さ $4.86 \mathrm{~mm}$ )および短織維(厚さ $10 \mathrm{~mm}$ )の不織布の 8 種類である。こ れらの強度特性を表一2に示す。

表 -1 試料の物理的特性

\begin{tabular}{|c|c|c|c|c|c|}
\hline \multirow{2}{*}{$\begin{array}{l}\text { 地盤 } \\
\text { 名称 }\end{array}$} & \multirow{2}{*}{$\begin{array}{c}\text { 土粒子 } \\
\text { 密度 } \\
\rho_{s} \\
\mathrm{~g} / \mathrm{cm}^{3} \\
\end{array}$} & \multirow{2}{*}{$\begin{array}{c}\text { 自然 } \\
\text { 含水比 } \\
w \\
\% \\
\%\end{array}$} & \multicolumn{3}{|c|}{ アッターベルグ限界 } \\
\hline & & & $\begin{array}{c}L L \\
\%\end{array}$ & $\begin{array}{c}P L \\
\%\end{array}$ & $\begin{array}{l}I_{p} \\
\%\end{array}$ \\
\hline $\begin{array}{l}\text { 構内 } \\
\square-ム\end{array}$ & 2.52 & 79.13 & 140.6 & 130.6 & 10.0 \\
\hline $\begin{array}{l}\text { ハッ木 } \\
\text { ローム }\end{array}$ & 2.62 & 62.59 & 106.9 & 64.2 & 42.7 \\
\hline 排水用砂 & 2.72 & 5.15 & NP & NP & - \\
\hline
\end{tabular}

表一2 ジオシンセティックスの強度特性

\begin{tabular}{|c|c|}
\hline 種類 & $\begin{array}{c}\text { 引張 ク強度 } \\
\mathrm{kgf} / \mathrm{cm}^{2}\end{array}$ \\
\hline HDPE & 340 \\
\hline EPDM & 100 \\
\hline PVC & 150 \\
\hline TPO & 150 \\
\hline 緎維補強 & \\
\hline CPE & 270 \\
\hline 長紻維不織布 & 63 \\
\hline 短織維不織布 & 3.4 \\
\hline
\end{tabular}




\section{3.実験装置および実験方法}

実験装置は、写真ー1に示すような、幅 $800 \mathrm{~mm}$ 、奥行き $400 \mathrm{~mm}$ 、厚さ $4 \mathrm{~mm}$ の鋼板 上にワイヤー巻き上げ器を取り付けた引張り 装置と、巻き上げ器からのワイヤーに連結さ れた荷重計、さらにジオシンセティックスを 装着し上載荷重としても機能する幅 $30 \mathrm{~cm}$ 、 長さ $40 \mathrm{~cm}$ 、高さ $40 \mathrm{~cm}$ 、重さ $118 \mathrm{kgf}$ のコン クリートブロックで構成される。なお、コン クリートブロックは持ち運びができるように 厚さ $10 \mathrm{~cm}$ の 4 個のブロックに分けられてい る。また、荷重計はゴム製の車輪が 4 つ付い た台車の上に金具で固定されている。引張り 装置は、鋼板の 4 隅に長さ $320 \mathrm{~mm}$ の鋼製ピ ンを打つことにより地盤に固定した。

供試体のジオシンセティックスの寸法は、 幅 $30 \mathrm{~cm}$ 、長さ $120 \mathrm{~cm}$ とした。通常状態に おいては、ストレートエッジを用いて地盤を 平滑にし、その上に供試体を地表面を乱さな いように敷設した。地盤を湿潤状態にする場 合は、地盤の表面に水膜ができるまで散水し、 ストレートエッジを用いてすばやく平滑に成 型し、水膜ができた状態で供試体を敷設した。

供試体の上面には、コンクリートブロック

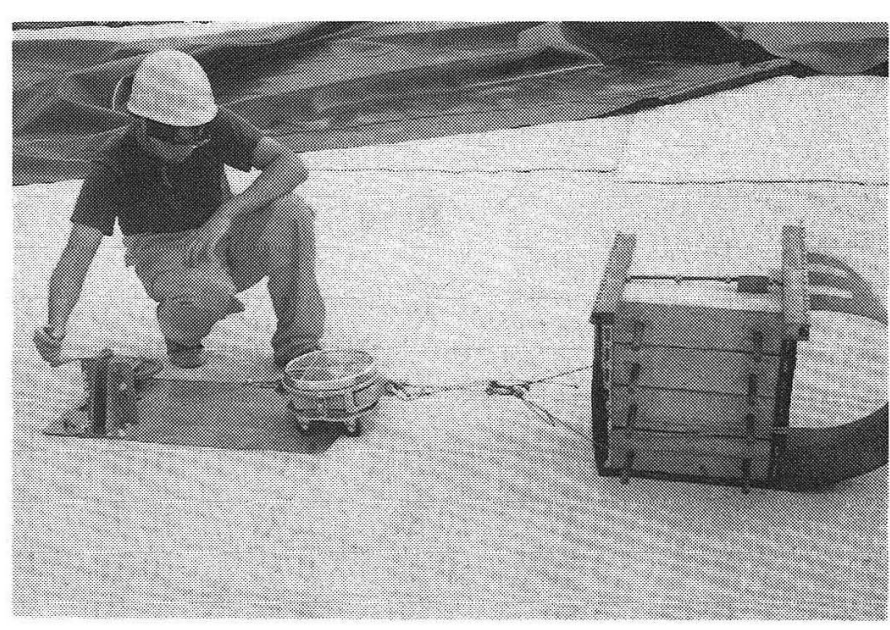

写真 -1 実験装置

表－3 地盤の土質特性

\begin{tabular}{|c|c|c|c|c|}
\hline \multirow[b]{2}{*}{$\begin{array}{l}\text { 地盤 } \\
\text { 名称 }\end{array}$} & \multicolumn{2}{|c|}{ 乾燥状態 } & \multicolumn{2}{|c|}{ 湿潤状態 } \\
\hline & $\begin{array}{c}\text { 平均 } \\
\text { 含水比 } \\
w \\
\% \\
\%\end{array}$ & $\begin{array}{c}\text { コーン } \\
\text { 指数 } \\
q_{\mathrm{c}} \\
\mathrm{kgf} / \mathrm{cm}^{2}\end{array}$ & $\begin{array}{c}\text { 平均 } \\
\text { 含水比 } \\
w \\
\% \\
\%\end{array}$ & $\begin{array}{c}\text { コーン } \\
\text { 指数 } \\
q_{\mathrm{c}} \\
\mathrm{kgf} / \mathrm{cm}^{2}\end{array}$ \\
\hline $\begin{array}{c}\text { 構内 } \\
\square-ム\end{array}$ & 79.13 & 5.55 & 108.9 & 2.60 \\
\hline $\begin{array}{l}\text { スッ木 } \\
\text { ローム }\end{array}$ & 62.59 & 3.16 & 113.61 & 1.67 \\
\hline $\begin{array}{l}\text { 排水 } \\
\text { 用砂 }\end{array}$ & 5.15 & 2.24 & 9.06 & $\begin{array}{l}0.75 \\
1.97\end{array}$ \\
\hline
\end{tabular}

を 4 段に重ねて供試体中央に置き、上載圧を作用させた。コンクリートブロックは 4 隅をアングルを用い て固定することにより、4 個のコンクリートブロックを一体化した。供試体の前・後端をコンクリートブ ロックに巻き付けて、一体化した後、地面からの高さ $10 \mathrm{~cm}$ の位置に、ワイヤーを地面と水平にコンクリ ートブロックと供試体を囲むように掛けて、シャックルを介して荷重計を接続した。その後、ワイヤー巻 き上げ器のハンドルを回転させ、荷重計の針がピーク抵抗值を示し一定となるまでコンクリートブロック に引張り力を与え続けた。なお、このときの回転速度は、荷重計の針の回転が連続になるように注意した。 測定終了後には、供試体の表面温度を測定した。

\section{4.実験結果および考察}

通常状態と湿潤状態について実験を行なった。 3 箇所の原地盤での含水比、 $5 \mathrm{~cm}$ 貫入時のコーン 指数は表一3に示す通りであった。埼玉県羽生市処分場建設現場では、排水用砂の上に敷かれた保 護用短繊維不織布の上においても、通常状態の試験を行った。 
実験により得られたピーク抵抗值 $\mathrm{T}$ をコンクリートブロックの重量 $\mathrm{N}$ で除してピーク時の摩擦係 数(以下、「摩摖係数」) $\mu \mathrm{p}$ を計算し、その結果を表 -4 に示す。

$$
\text { 表一4 ジオシンセティックスの摩擦特性 }\left(\mu=\frac{T}{N}\right)
$$

\begin{tabular}{|c|c|c|c|c|c|c|c|c|c|c|}
\hline \multirow[b]{3}{*}{ 下地 } & \multirow[b]{3}{*}{ 状態 } & \multicolumn{8}{|c|}{ ジオシンセティックスの種類 } & \multirow{3}{*}{$\begin{array}{l}\text { シートの } \\
\text { 平均 } \\
\text { 温度 } \\
{ }^{\mathrm{C}}\end{array}$} \\
\hline & & \multicolumn{6}{|c|}{ シオメンブレン } & \multicolumn{2}{|c|}{ 不織布 } & \\
\hline & & HDPE & EPDM & PVC & $\begin{array}{c}\text { シボ付き } \\
\text { HDPE }\end{array}$ & TPO & $\begin{array}{c}\text { 綫維補強 } \\
\text { CPE }\end{array}$ & $\begin{array}{l}\text { 長織維 } \\
\text { 不織布 }\end{array}$ & $\begin{array}{l}\text { 短䌮維 } \\
\text { 不織布 }\end{array}$ & \\
\hline 構内 & 通常 & 0.47 & 0.84 & 0.77 & 0.94 & 0.53 & 0.72 & 0.77 & 0.78 & 19.4 \\
\hline$\square-ム$ & 湿潤 & 0.35 & 0.64 & 0.55 & 0.73 & 0.44 & 0.53 & 0.71 & 0.73 & 13.8 \\
\hline 八ッ木 & 通常 & 0.29 & 0.90 & 0.69 & 0.90 & 0.36 & 0.48 & 0.88 & $※ 1$ & 38.5 \\
\hline ロ-ム & 湿潤 & 0.23 & 0.51 & 0.45 & 0.84 & 0.27 & 0.46 & 0.68 & $※ 1$ & 39.6 \\
\hline 排水 & 通常 & 0.48 & 0.67 & 0.64 & 0.79 & 0.61 & 0.63 & 0.73 & 0.74 & 28.4 \\
\hline 用砂 & 湿潤 & 0.40 & 0.64 & 0.62 & 0.77 & 0.53 & 0.61 & 0.69 & 0.78 & 30.3 \\
\hline $\begin{array}{l}\text { 短織維 } \\
\text { 不織布 }\end{array}$ & 乾燥 & 0.38 & $※ 2$ & 0.73 & $※ 2$ & 0.54 & 0.71 & 0.67 & - & 37.5 \\
\hline
\end{tabular}

※ 1 一は実施せず。

※ 2 下地が短絨維不織布の場合の EPDM、シボ付きHDPEはピーク強度計測不可能。

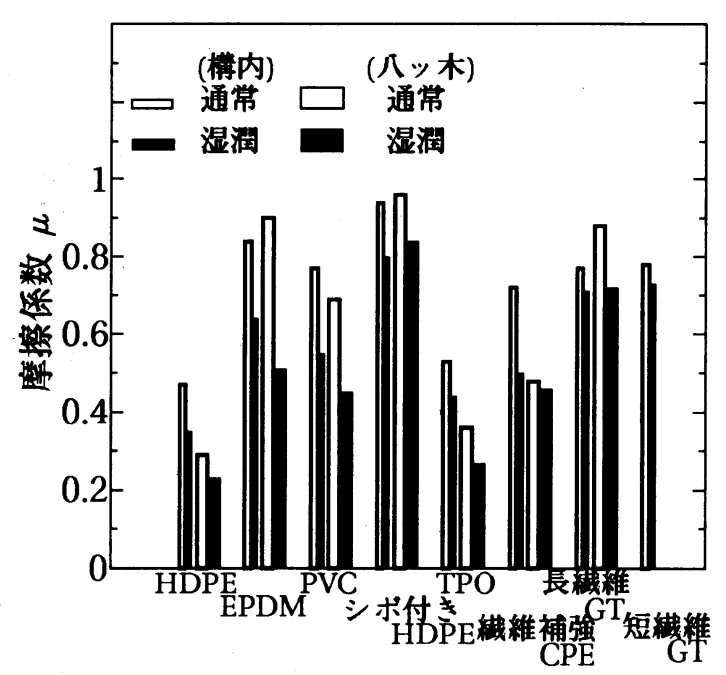

a ローム

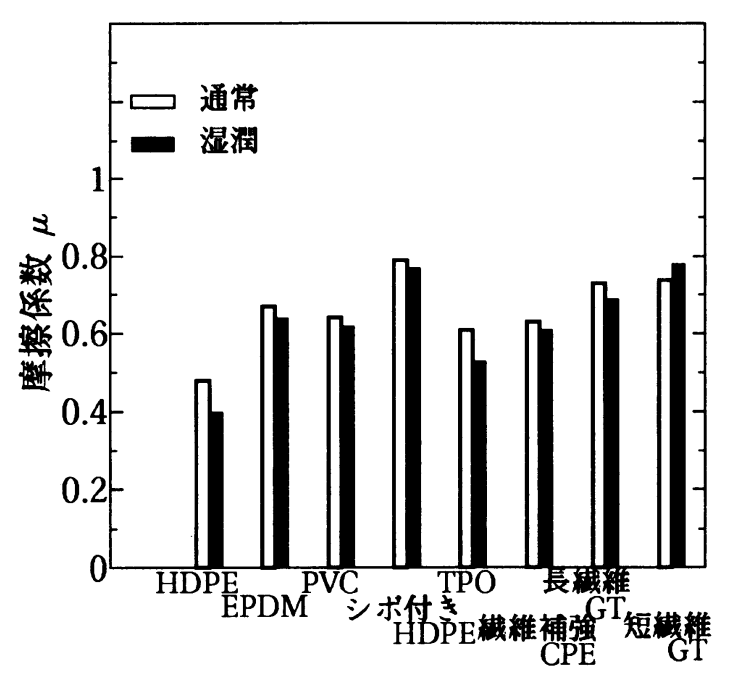

b 排水用砂

図-1 ピーク時摩擦保数

さらに、ロームおよび砂の通常状態および湿潤状態におけるジオシンセティックスとの摩擦係数を比較 して整理したものを、図ー1-a〜1-bに示す。通常状態、湿潤状態とも同様に、ロームおよび排水用砂に対 してシボ付きHDPE、EPDM、長繊維および不織布の摩擦係数が高い傾向にあることがわかる。

次に、構内ローム、八ッ木ローム、排水用砂とジオシンセティックスとの摩擦係数を通常状態 $\mu$ nor と湿 
潤状態 $\mu$ wet とで比較したものを図ー2-a〜2-c に示した。湿潤状態において、ロームでは平均的に通常状

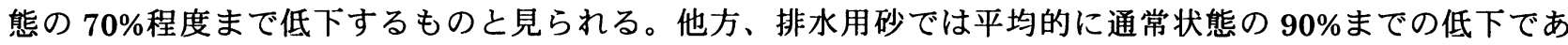
る。

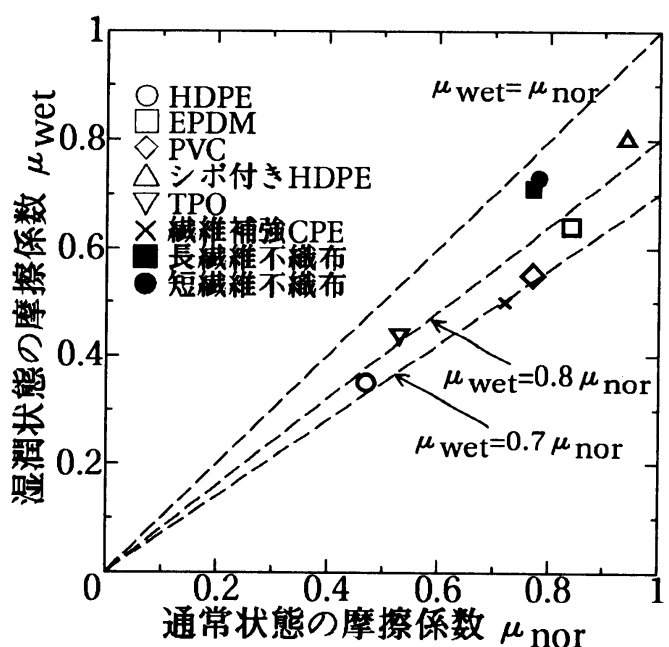

a 構内ローム

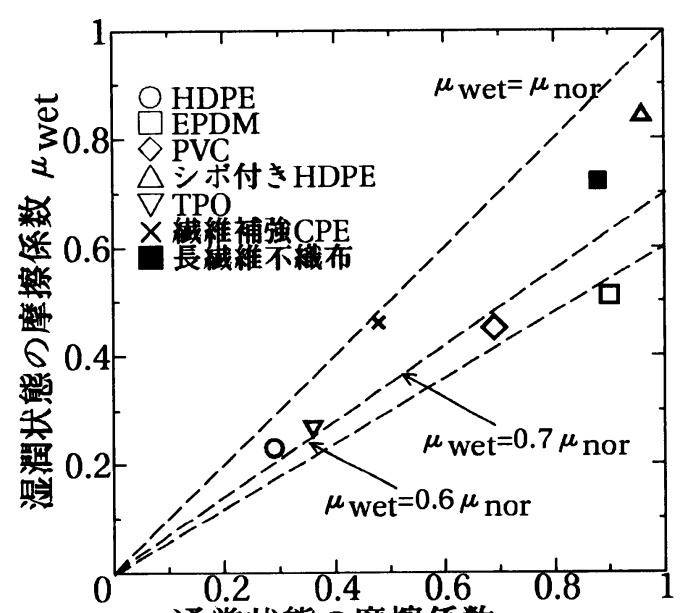

通常状態の摩擦係数 $\mu_{\text {nor }}$

b 八ッ木ローム

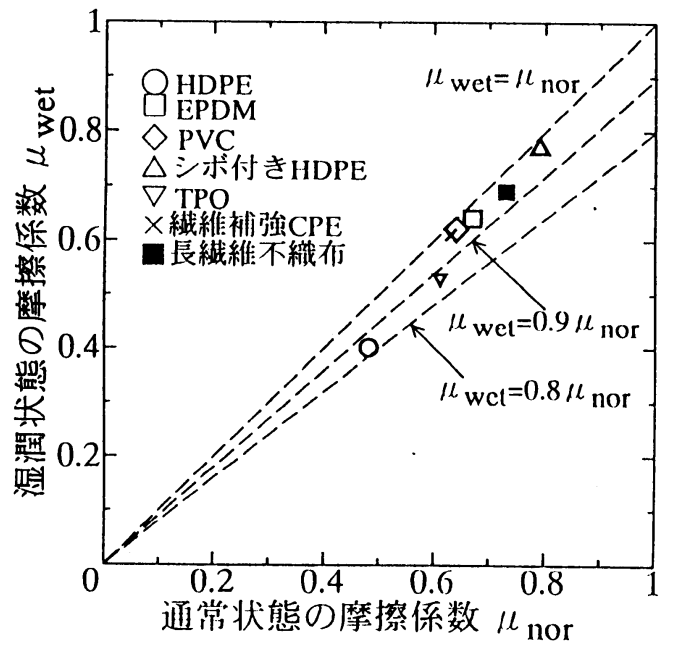

C 排水用砂

図-2 通常状態と湿潤状態の摩擦係数の比較

ここで、湿潤状態における通常状態に対する摩擦係数の減少率を $\alpha=1-\mu_{\text {wet }} / \mu_{\text {nor }}$ と定義して、これ と通常状態における摩擦係数との関係を図ー3-a〜3-bに示した。ロームの場合、減少率は 0.05〜0.45の範 囲にあり、通常状態の摩擦係数 $\mu$ nor が増大するにつれて、减少率も増大する傾向にある。このうち、長織 維不織布、シボ付き HDPE のような表面性状の粗いものは減少率が低い。排水用砂の場合、HDPE、TPO は 0.13 0.15 と減少率がやや大きいが、その他のものの減少率は $0.03 \sim 0.06$ とかなり小さい。これは、砂 地盤の場合、水膜ができにくいためと考えられる。 


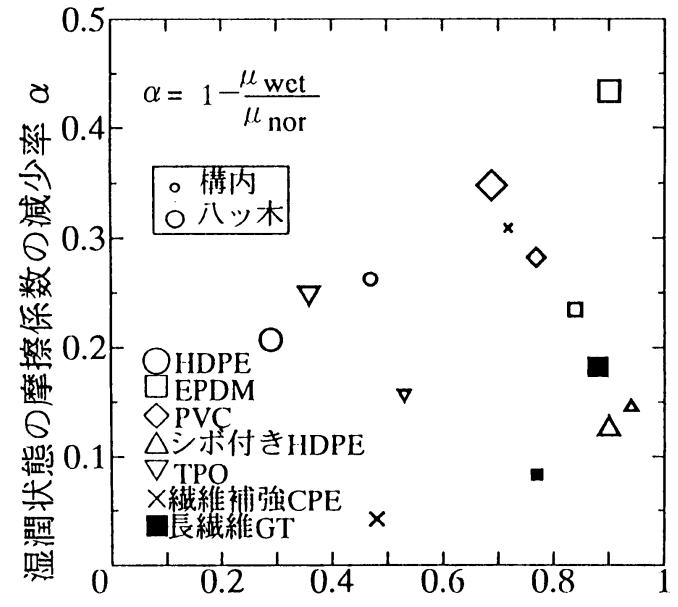

通常状態の摩擦係数 $\mu$ nor

a ローム

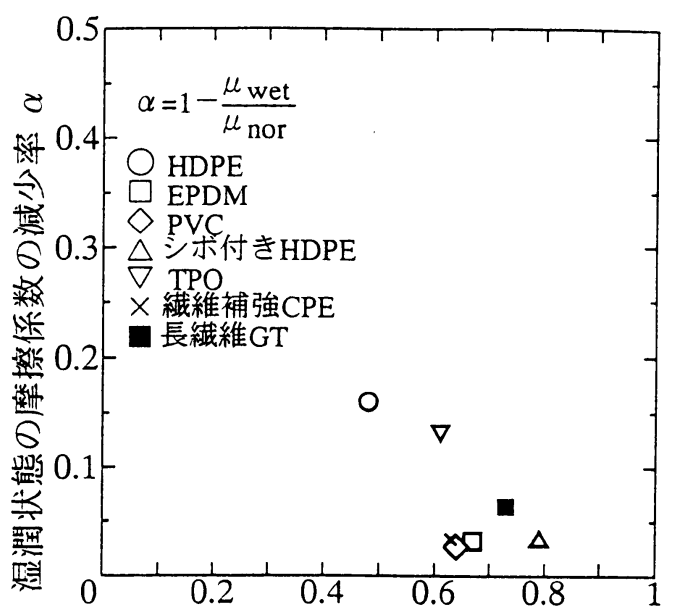

通常状態の摩擦係数 $\mu$ nor

b 排水用砂

図-3 通常状態の摩摖係数と減少率 $\alpha$ との関係

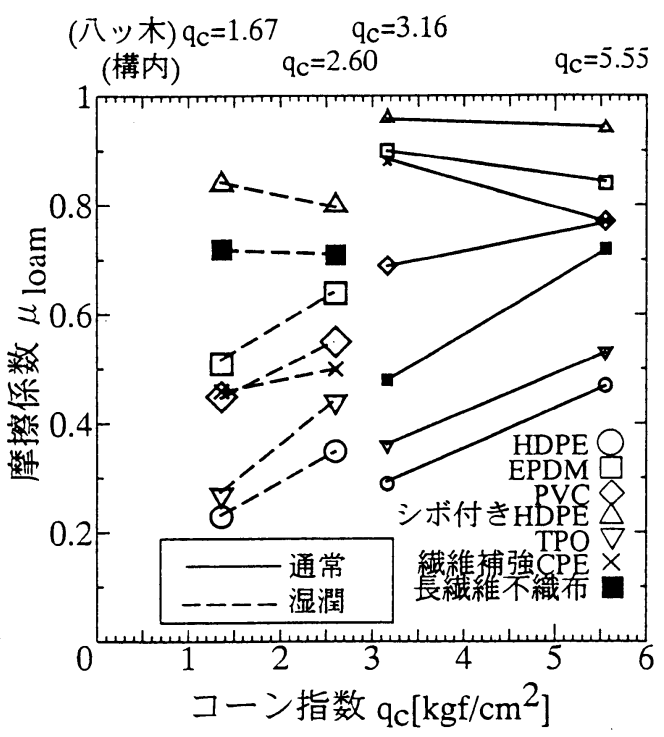

a ローム

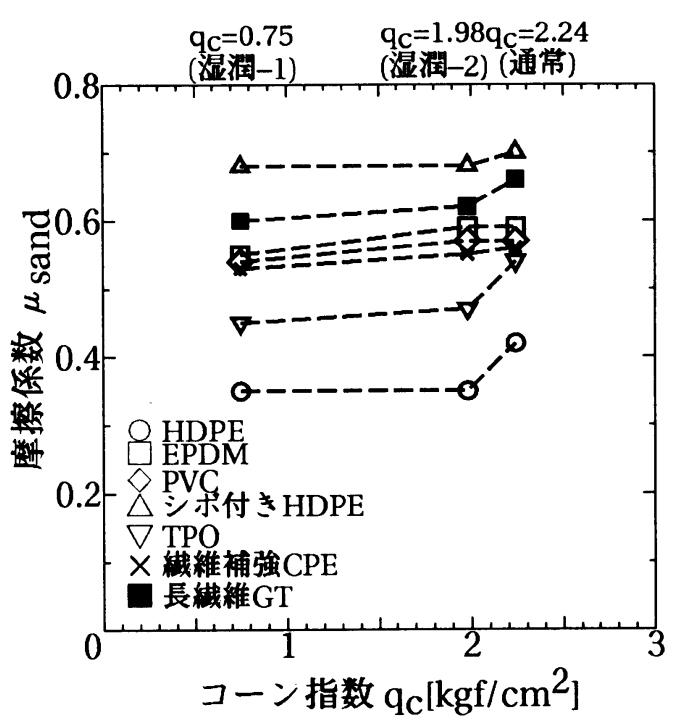

b 排水用砂

図-4 コーン指数と摩擦係数の関倸

図ー4-a〜4-b はロームおよび排水用砂のコーン指数と摩擦係数との関係を示したものである。なお、ロ 一ムの場合、通常状態、湿潤状態別にコーン指数と摩擦係数との関係を示した。通常状態においては、シ ボ付き HDPE、EPDM、繊維補強 CPE のような表面が粗いものはコーン指数の增加とともに摩擦係数は減 少し、PVC、長繊維不織布、TPO、HDPE はコーン指数の増大とともに摩擦係数が増大する傾向が見られ た。湿潤状態においては、シボ付き HDPE と長繊維不織布はコーン指数の増大とともに摩擦係数がわずか に減少するが、その他は増大する傾向にある。他方、排水用砂の場合、湿潤状態におけるコーン指数の変 化に伴う摩擦係数の変化が小さいことから、コーン指数すなわち強度の違いよりも表面の水分性状の違い の影響の方が大きいと考えられる。 
一般にジオシンセティックスー不織布間の摩摖係数は、ジオシンセティックスー土間の摩擦係数よりも 小さいと考えられている 1)。そこで、そのことを検証するために、排水用砂に敷かれた短織維不織布上で の原位置摩擦試験の結果 $\mu_{\mathrm{gt}}$ と通常状態のローム上での結果 $\mu_{\text {loam }}$ おび乾燥排水砂上での結果 $\mu$ sand との 関係を示したのが図ー5-a〜5-b である。なお、シボ付き HDPE と EPDM を短織維不織布で試験した場合、 シートと不織布の間で相対変位が生じる以前に短繊維不織布上と下層の排水砂との間で相対変位が生じた ため、図および表には記載していない。図-5-a〜5-bより、短織維不織布上での摩擦係数は、八ッ木ロー ム上での值と比較すると 5 ３0\%大きくなっており、構内ロームと比較すると HDPE、長織維不織布の場 合は 5〜10\%小さく、その他のジオシンセティックスについては同程度である。排水用砂と比較すると、 HDPE、長織維不織布、TPO については 5 10\%小さく、織維補強 CPE、PVCについては 5\%大きくなっ ている。いずれにしても、今回の結果では、各種ジオシンセティックスの対短織維不織布との摩擦係数は、 ローム、排水用砂と比較したとき 5 〜 10\%以内の違いである。

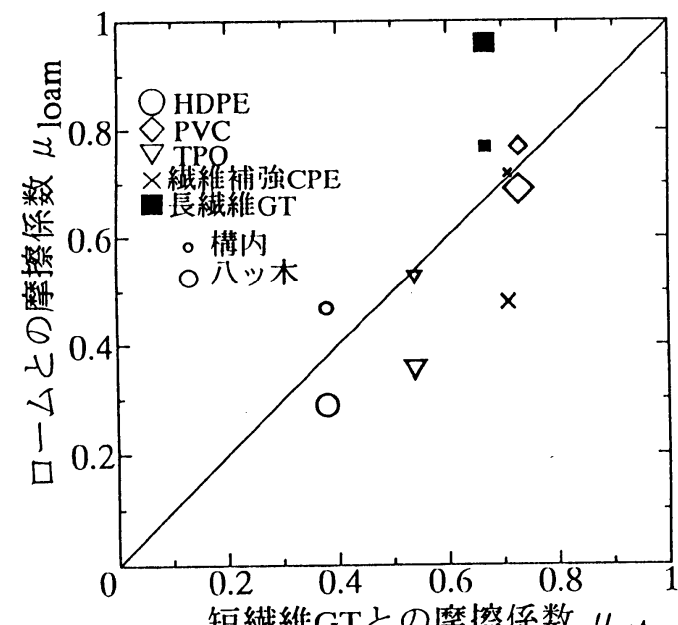

短繊維GTとの摩擦係数 $\mu_{\mathrm{gt}}$

a ローム

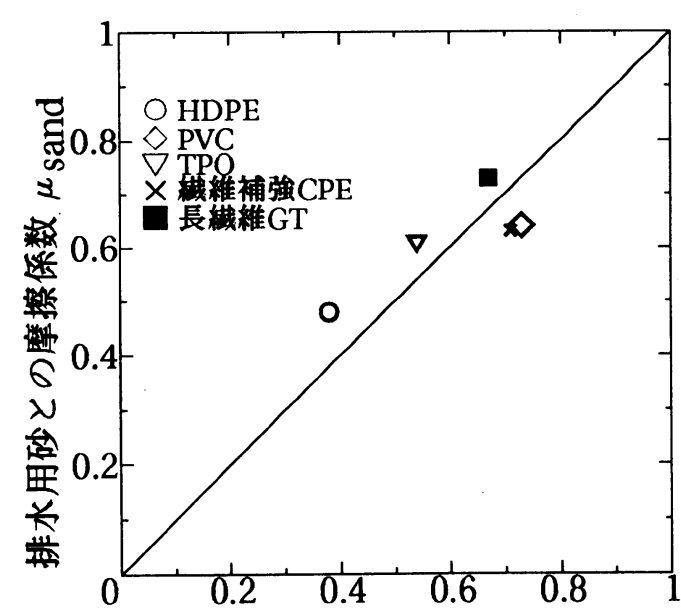

短織維GTとの摩擦係数 $\mu \mathrm{gt}$

b 排水用砂

図-5 ジオメンブレン/土 と ジオメンブレン/短綫維不織布 の摩擦係数の比較

図一6-a は、排水用砂上に敷かれた短織維不織布に対して得られた HDPE、EPDM、PVC、TPO の摩摖 係数 $\mu \mathrm{gt}$ と $100 \times 200 \mathrm{~mm}$ のせん断箱を使用した室内摩摖試験より得られた結果とを比較したものである PVC の摩擦係数は室内摩擦試験より得られた值とほほ等しくなっているが、その他の 3 ケースについては 現場摩摖試験の方が大きい值になっている。図一6-b は室内すなわち直応力 $\sigma \mathrm{n}$ とせん断抵抗值 $\tau_{\mathrm{p}}$ との関 係を示したものである。図一6-a に示した室内せん断試験の摩擦係数 $\mu$ lab は、各直線の傾きを用いて算出 したものであるが、図ー6-b においては各関係とも幾分の切片すなわち見かけの粘着力が見られる。した がって、図ー6-aにおいて現場での摩擦係数 $\mu$ が室内試験から得られた摩擦係数 $\mu$ lab り大きいのは、こ のような見かけの粘着力も摩摖抵抗力に取り入れて評価したためと考えられる。図一6-cには、室内試 験の結果に現場試験での $\sigma_{\mathrm{n}} 、 \tau_{\mathrm{p}}$ をプロットしてあるがこれらは室内試験の関係直線上にうまく対応して いると言える。 


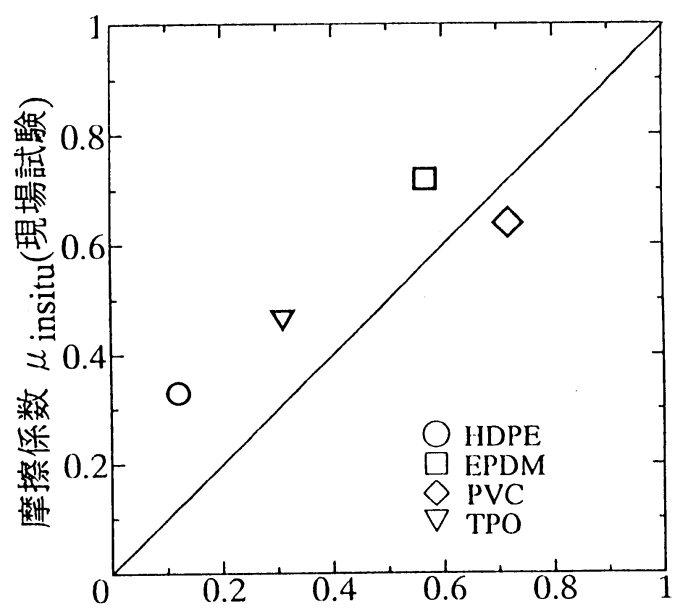

摩摖係数 $\mu$ lab(室内摩擦試颐)

a 摩擦係数の比較

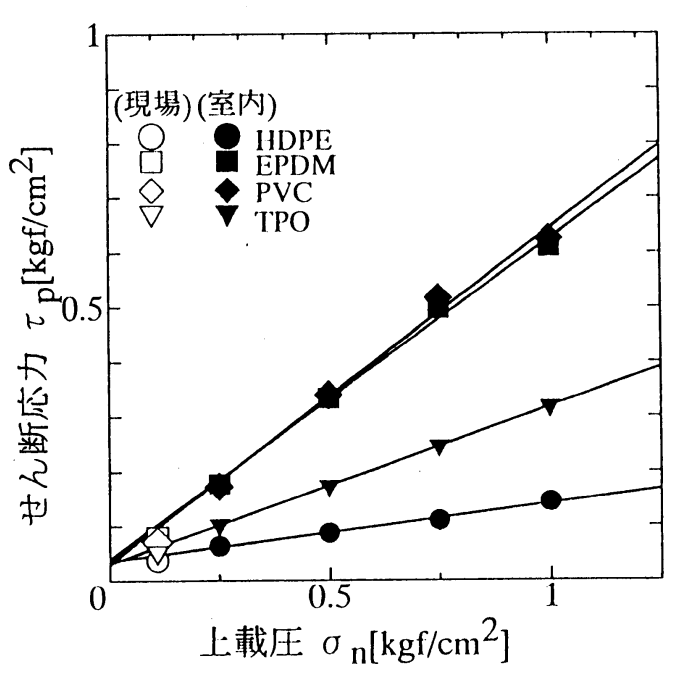

b $\sigma_{n}-\tau_{p}$ 関係

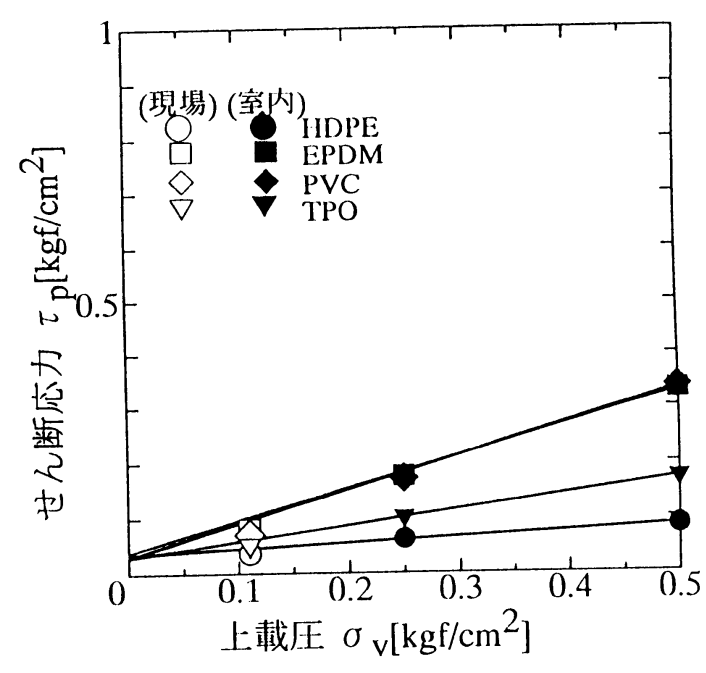

c $\sigma_{n}-\tau_{p}$ との対応

図-6 原位置試験結果と室内試験結果との対応

\section{5.結論}

土のせん断抵抗は、種類のみならず土の含水比や締固め度に依存する。そこで、ジオシンセティックス と土との摩擦特性を原位置で評価することのできる簡易な試験装置を試作した。本装置を用いた場合、鈶 直応力は $\sigma_{\mathrm{n}}=0.10 \mathrm{kgf} / \mathrm{cm}^{2}$ であり、得られた摩擦係数を埋立て層の深い処分場の設計に用いるには幾つかの 問題点もあるが、固定工や廃棄物投入以前の施工中でのジオシンセティックスの検討には使用し得るもの と考える。 
本実験によって得られた結論は次のようである。

1.湿潤状態の摩擦係数を通常状態と比較した場合、ロームでは $60 \sim 70 \%$ 、排水用砂では $90 \%$ となり、砂の 場合に比較してロームの方が摩擦係数の隇少率が大きい。

2.各種ジオシンセティックスの対短織維不織布との摩擦係数をロームおよび排水用砂と比較すると 5〜 10\%程度の違いである。

3.短繊維不織布とジオシンセティックスとの現場摩擦試験と室内摩摖試験の結果を比較すると、本実験の 結果の方が摩擦係数を大きく評価するが、室内試験の $\sigma_{n}-\tau_{\mathrm{p}}$ 関係とよく対応する。

本研究に際して住友建設（株）の土居洋一氏には、コンクリートブロックの作成、八ッ木ロームでの実 験等大変お世話になった。記して感謝申し上げる次第です。

\section{参考文献}

1)今泉繁良・内藤裕之・横山幸満・坪井正行:ジオメンブレンと豊浦砂の層間摩擦特性,土木学会第 50 回年次学術講演 会講演概要集 3-B, pp.1558-1559, 1995

2)三木博史・林義之:国内におけるジオメンブレンの現状,第 1 回ジオメンブレン技術に関するセミナー, pp.28-46, 1994 3)鈴木正人・佐々木宏二・中岛典昭:表面遮水工構成材料の境界摩摖特性,土木学会第 49 回年次学術講演概要集 $2, \mathrm{pp} .1246-$ 1247,1994

4)今泉繁良・高橋 悟・横山幸満・坪井正行:ジオシンセティックス多層ライナーに生じる張力の評価, 土木学会第 51 回年次 学術講演会講演概要集 3-B, pp.682-683, 1996

5)坪井正行・今泉繁良・横山幸満・宮地秀樹:遮水シートの層間摩擦抵抗,廃棄物学会第 7 回研究発表会講演論文集, pp.706- 709, 1996 